\title{
A new phenotype of anorexia nervosa: the changing shape of eating disorders
}

\author{
Melissa Whitelaw ${ }^{1,2,3,4^{*}}$, Heather Gilbertson ${ }^{1,3,4}$, Katherine J Lee ${ }^{3,4}$, Mick B Creati ${ }^{2}$, Susan M Sawyer ${ }^{2,3,4}$ \\ From 2013 ANZAED Conference: Inspiring Change: Person and Context \\ Melbourne, Australia. 23-24 August 2013
}

\section{Background and aims}

Adolescents are increasingly referred to our specialist eating disorder (ED) program having lost large amounts of weight and having the diagnostic features of anorexia nervosa (AN) with the exception of underweight. Many of these adolescents with EDNOS-AN[wt] were premorbidly overweight. We aimed to identify the changing prevalence of this phenotype from 2005-2010 in an inpatient sample, and compare the associated complications with adolescents with AN.

\section{Methods}

A 6-year retrospective cohort study was undertaken of adolescents admitted to hospital for the first time for refeeding. All patients met DSM-IV diagnostic criteria for AN $(\mathrm{N}=72)$ or EDNOS-AN[wt] $(\mathrm{N}=28)$. Baseline medical data are reported.

\section{Results}

In 2005, EDNOS-AN[wt] represented 7.7\% of first admissions, rising 6 -fold to $46.0 \%$ by 2010 . Hypophosphataemia $(<1.10 \mathrm{mmol} / \mathrm{L})$ developed in $38.9 \%$ of AN and $28.6 \%$ of EDNOS-AN[wt] inpatients. Bradycardia (pulse rates $<50$ bpm) occurred in $33.3 \%$ of AN and $46.4 \%$ of EDNOS-AN [wt] patients, while pulse rates $<40 \mathrm{bpm}$ occurred in $25.0 \%$ and $32.0 \%$ respectively.

\section{Conclusions}

A dramatic increase in the proportion of adolescents admitted with EDNOS-AN[wt] is evident. The rate of severe medical complications is concerning, and suggests that significant weight loss can be life-threatening in adolescents, even when they are not underweight.

\footnotetext{
* Correspondence: melissa.whitelaw@rch.org.au

'Department of Nutrition and Food Services, The Royal Children's Hospital, Australia

Full list of author information is available at the end of the article
}

This abstract was presented in the Anorexia Nervosa Characteristics and Treatment stream of the 2013 ANZAED Conference.

\section{Authors' details}

'Department of Nutrition and Food Services, The Royal Children's Hospital, Australia. ${ }^{2}$ Centre for Adolescent Health The Royal Children's Hospital, Australia. ${ }^{3}$ Department of Paediatrics, The University of Melbourne, Australia. ${ }^{4}$ Murdoch Children's Research Institute, Australia.

Published: 14 November 2013

doi:10.1186/2050-2974-1-S1-O44

Cite this article as: Whitelaw et al:: A new phenotype of anorexia nervosa: the changing shape of eating disorders. Journal of Eating Disorders 2013 1(Suppl 1):044.
Submit your next manuscript to BioMed Central and take full advantage of:

- Convenient online submission

- Thorough peer review

- No space constraints or color figure charges

- Immediate publication on acceptance

- Inclusion in PubMed, CAS, Scopus and Google Scholar

- Research which is freely available for redistribution
( Biomed Central

\section{Ciomed Central}

